\title{
Using consumption rate to assess potential predators for biological control of white perch
}

\author{
N.J.C. Gosch ${ }^{(1,2)}$, K.L. Pope ${ }^{(3)}$ \\ Received December 22, 2010 \\ Revised March 22, 2011 \\ Accepted March 30, 2011
}

Key-words:

biological

control,

predation, consumption

rate, white

perch,

Morone

americana

\section{ABSTRACT}

Control of undesirable fishes is important in aquatic systems, and using predation as a tool for biological control is an attractive option to fishery biologists. However, determining the appropriate predators for biological control is critical for success. The objective of this study was to evaluate the utility of consumption rate as an index to determine the most effective predators for biological control of an invasive fish. Consumption rate values were calculated for nine potential predators that prey on white perch Morone americana in Branched Oak and Pawnee reservoirs, Nebraska. The consumption rate index provided a unique and insightful means of determining the potential effectiveness of each predator species in controlling white perch. Cumulative frequency distributions facilitated interpretation by providing a graphical presentation of consumption rates by all individuals within each predator species. Largemouth bass Micropterus salmoides, walleye Sander vitreus and sauger S. canadensis were the most efficient white perch predators in both reservoirs; however, previous attempts to increase biomass of these predators have failed suggesting that successful biological control is unlikely using existing predator species in these Nebraska reservoirs.

\section{RÉSUMÉ}

Utilisation du taux de consommation dans l'évaluation des prédateurs potentiels pour un contrôle biologique de la perche blanche

Mots-clés : contrôle biologique, prédation, taux de consommation,
Le contrôle des poissons indésirables est important dans les écosystèmes aquatiques et l'utilisation de la prédation comme outil de contrôle biologique est une option attractive pour les biologistes des pêches. Toutefois, déterminer les bons prédateurs pour un contrôle biologique est crucial pour sa réussite. L'objectif de cette étude a été de tester l'utilité du taux de consommation comme indice de détermination des prédateurs les plus appropriés pour le contrôle biologique d'un poisson invasif. Les valeurs du taux de consommation ont été calculées pour neuf prédateurs potentiels de la perche blanche Morone americana dans les réservoirs

(1) Nebraska Cooperative Fish and Wildlife Research Unit, and School of Natural Resources, University of Nebraska-Lincoln, Lincoln, 68583-0984 NE, USA

(2) U.S. Army Corps of Engineers, 601 East 12th Street, Kansas City, 64106 MO, USA,

Nathan.J.Gosch@usace.army.mil

(3) U.S. Geological Survey, Nebraska Cooperative Fish and Wildlife, Research Unit, and School of Natural

Resources, University of Nebraska-Lincoln, Lincoln, 68583-0984 NE, USA 
perche blanche, Morone americana
Branched Oak et Pawnee, Nébraska. L'indice du taux de consommation est un moyen unique et perspicace pour déterminer l'effectivité potentielle de chaque espèce de prédateur dans le contrôle de la perche blanche. Les distributions de fréquences cumulées facilitent l'interprétation en donnant une représentation graphique des taux de consommation par tous les individus d'une même espèce de prédateur. Le bass à grande bouche Micropterus salmoides, les sandres Sander vitreus et $S$. canadensis sont les prédateurs les plus efficaces de la perche blanche dans les deux réservoirs. Toutefois des tentatives antérieures pour augmenter la biomasse de ces prédateurs n'ont pas réussi, suggérant que le contrôle biologique est improbable avec les espèces de prédateurs présentes dans ces réservoirs du Nébraska.

\section{INTRODUCTION}

Fishery biologists face many challenges while attempting to maximize fishing opportunities for anglers. One major challenge for fishery biologists is the control (i.e., reduction or elimination) of undesirable fishes. Numerous criteria are used to determine if a species is undesirable including lack of recreational value to anglers and negative effects on native, endangered or popular sportfish populations (Wydoski and Wiley, 1999). Fishery biologists have several options to control undesirable fishes, namely chemical, mechanical and biological control. Although often effective, the use of chemicals to control undesirable fishes usually creates numerous economic, social and political concerns. Thus, chemical control is losing popularity among fishery agencies despite prior widespread use (Bettoli and Maceina, 1996). Mechanical control is labor-intensive and usually only effective as a short-term solution (Wydoski and Wiley, 1999). Biological control of undesirable fishes, however, is an attractive option to fishery biologists because cost is minimal, machinery and toxic chemicals are absent and results are longer lasting (Sierp et al., 2009). Further, increasing the abundance of piscivores to control undesirable fishes is particularly attractive (Wydoski and Wiley, 1999) because, if successful, this option can lead to increased numbers of piscivores that can benefit anglers.

The white perch Morone americana is native to the east coast of North America (Scott and Crossman, 1973); however, it is an invasive species in the Midwest currently found in Kansas, Missouri and Nebraska (Hodkin, 2001; Kuklinski, 2007). This species tends to overpopulate and stunt in inland waters outside of its native range (Scott and Crossman, 1973). White perch are highly fecund (Mansueti, 1961), have an ability to reproduce during their first year of life and can withstand a wide range of environmental conditions allowing quick establishment of this species in new water bodies (Ballinger and Peters, 1978; Hodkin, 2001). White perch often dominate fish communities within three years of discovery in Midwest reservoirs (Hergenrader and Bliss, 1971; Hergenrader, 1980; Jackson, 1999, 2008; Hodkin, 2001). Chemical removal of white perch in some of these Midwestern reservoirs has been successful (Hergenrader and Bliss, 1971; Hergenrader, 1980); however, white perch was not extirpated from the drainage basins of these reservoirs and this species was able to disperse to new waters (Bliss and Schainost, 1974; Ballinger and Peters, 1978; Jackson, 1999, 2008). Chemical control of white perch in Midwestern reservoirs has again been suggested (Vrtiska et al., 2001); however, biological control is a more attractive option because of the aforementioned disadvantages of chemical and mechanical control. Determining the appropriate predator for biological control within a given water body is important. Increasing the biomass of the appropriate predator is a prerequisite to successful biological control; if increased biomass cannot be achieved, biological control alone will not be successful. The objective of this study was to evaluate the utility of Thistle's foraging success (Thistle, 2006; hereafter referred to as consumption rate) as an index to determine the most effective predators for biological control of white perch in two Midwest reservoirs. 


\section{MATERIALS AND METHODS}

\section{> STUDY RESERVOIRS}

Branched Oak Lake, located in Lancaster County, Nebraska, is a 728-ha, eutrophic (trophic state index value of 59.2; Callam, 1996) flood-control reservoir. White perch was discovered in Branched Oak Lake, Nebraska during the 1987 Nebraska Game and Parks Commission (NGPC) annual gillnet survey (Porath, M.T., NGPC, personal communication). Similar to other Nebraska reservoirs (Hergenrader and Bliss, 1971; Hergenrader, 1980), white perch dominated the biomass of the Branched Oak fish community within a few years of discovery. Similar to white perch, gizzard shad Dorosoma cepedianum also established a high-density population because of abundant production of age-0 fish (Gosch et al., 2010). At the time of study, Branched Oak Lake had restrictive harvest regulations (i.e., catch-and-release fishing for hybrid striped bass $M$. saxatilis $\times M$. chrysops and flathead catfish Pylodictis olivaris, a daily bag limit of 1 walleye Sander vitreus longer than $56 \mathrm{~cm}$, and a 25-cm minimum length limit for white crappie Pomoxis annularis and black crappie $P$. nigromaculatus).

Pawnee Lake is a 299-ha, eutrophic (trophic state index value of 66.6; Callam, 1996) floodcontrol reservoir that is located $14 \mathrm{~km}$ south of Branched Oak Lake in Lancaster County, Nebraska. White perch was discovered in 2001 and has dominated the Pawnee fish community since 2005 (Jackson, 2008). Gizzard shad was extirpated from Pawnee Lake during the winter of 2000-2001 (Porath, 2006; Jackson, 2008). At the time of study, Pawnee Lake had less restrictive harvest regulations (i.e., daily bag limit of 10 panfish) compared to Branched Oak Lake.

\section{> FIELD METHODS AND ANALYSIS}

Stock-length (Gabelhouse, 1984) piscivorous fishes (largemouth bass Micropterus salmoides, white crappie, black crappie, channel catfish Ictalurus punctatus, flathead catfish, white bass Morone chrysops, hybrid striped bass, sauger Sander canadensis and walleye) were sampled during the ice-free period (approximately March through November) of 2006 and 2007 in Branched Oak and Pawnee reservoirs, Nebraska with a boat-mounted electrofisher (pulsed DC). Each reservoir was sampled twice a week. Captured individuals were weighed $(\mathrm{g})$. Stomach contents of captured fishes were removed using pulsed gastric lavage (Light et al., 1983; Kamler and Pope, 2001) and preserved in a 10\% buffered-formalin solution. After the stomach was flushed, an appropriately-sized clear plastic tube was inserted into the digestive tract and used as a gastroscope to ensure that all stomach contents were removed. Fish were then released.

Predator species captured with fewer than 10 individuals that contained prey items in their stomach were excluded from analyses. In Branched Oak Lake, analysis of prey fishes was limited to white perch and gizzard shad because more than $92 \%$ of the volume of prey fishes consumed by predators consisted of white perch and gizzard shad (Gosch et al., 2010). In Pawnee Lake, analysis of prey fishes was restricted to white perch because more than $82 \%$ of the volume of prey fishes consumed by predators consisted of white perch (Gosch et al., 2010).

Consumption rate was used to determine the effectiveness of each predator to consume fish. Consumption rate $(C R)$ is the volume (determined by volume displacement of water) of a prey item consumed per $\mathrm{kg}$ of a particular predator and is quantified as: $C R=V_{i} / W_{j}$ where $V_{i}$ is the volume $(\mathrm{mL})$ of prey item $i$ (either white perch or gizzard shad) in the stomach of predator $j$ and $W_{j}$ is the weight $(\mathrm{kg})$ of predator $j$. If multiple items of the same prey type were found in a predator stomach, the volumes were combined. Box plots were constructed and median consumption rate values on white perch were compared among predators in each reservoir using a Kruskal-Wallis non-parametric ANOVA because the data were not normally distributed. Dunn's multiple comparison procedure was used for all pairwise comparisons. 
Cumulative frequency distributions of consumption rates were constructed to compare the relative effectiveness of each predator species to consume two fishes (i.e., white perch and gizzard shad) in Branched Oak Lake; Pawnee Lake was excluded from this analysis because gizzard shad was not present in Pawnee Lake during this investigation. Cumulative frequency distributions illustrate the percentage of individuals that have a consumption rate value equal to or less than the plotted consumption rate value. The cumulative distribution always begins at a relative frequency of 0 and ends at a relative frequency of 1; a Sigmoid-shaped cumulative curve indicates data that are normally distributed, whereas a concave downward (upward) curve indicatives data that are positively (negatively) skewed. Thus, cumulative frequency distributions that are primarily located in the upper left corner of the graph are indicative of a skewed distribution toward low consumption rate values for a given predator population. Cumulative frequency distributions of consumption rate on white perch and on gizzard shad for each predator were compared using a Kolmogorov-Smirnov test.

\section{RESULTS}

Consumption rate values on white perch ranged from 0 to 95 with a median of 0 being common for predators in both reservoirs during 2006 and 2007 (Figure 1). Median consumption rate on white perch differed among predators within reservoirs and among years (Figure 1). During 2006 in Branched Oak Lake, largemouth bass consumption rate on white perch was greater than all other predators (Figure 1). In Pawnee Lake, walleye and sauger consumption rate on white perch was greater than all other predators, followed closely by largemouth bass (Figure 1). During 2007 (a wetter year with increased water levels that inundated large tracks of terrestrial vegetation including woody plants) in Branched Oak Lake, walleye consumption rate on white perch was greater than any other predator (Figure 1). In Pawnee Lake, walleye and sauger consumption rate on white perch was greater than all other predators (Figure 1). Cumulative frequency distributions of consumption rate on white perch differed from cumulative frequency distributions of consumption rate on gizzard shad in Branched Oak Lake during 2006 for largemouth bass, white crappie and flathead catfish, but not for black crappie, channel catfish, hybrid striped bass and walleye (Figure 2), and during 2007 for white crappie, flathead catfish and walleye, but not for hybrid striped bass (Figure 2). Flathead catfish consumed greater amounts of white perch than gizzard shad during both 2006 and 2007. Largemouth bass (during 2006) and walleye (during 2007) consumed greater amounts of white perch than gizzard shad. Conversely, white crappie consumed greater amounts of gizzard shad than white perch during both 2006 and 2007.

\section{DISCUSSION}

Largemouth bass and Sander species were the most efficient (per-kg basis) white perch predators in Branched Oak and Pawnee reservoirs; these predators had the greatest consumption rate on white perch. Thus, increasing the biomass of these predators would be ideal if the primary management objective for Branched Oak and Pawnee reservoirs is control of white perch populations. Ultimately, this recommendation presents major challenges for the fishery biologists of Branched Oak and Pawnee reservoirs. Efforts during the past 20 years to increase the populations of largemouth bass and walleye have largely been unsuccessful (e.g., Jackson, 1999).

The presence of gizzard shad adds another major challenge to the success of biological control via predation in Branched Oak Lake. All predators consumed gizzard shad, often in large amounts (Gosch et al., 2010), and white crappie consumed greater amounts of gizzard shad than white perch. All predators shifted from primarily consuming white perch during spring and early summer to primarily consuming gizzard shad during mid- to latesummer and throughout autumn in response to abundant production of age- 0 gizzard shad 


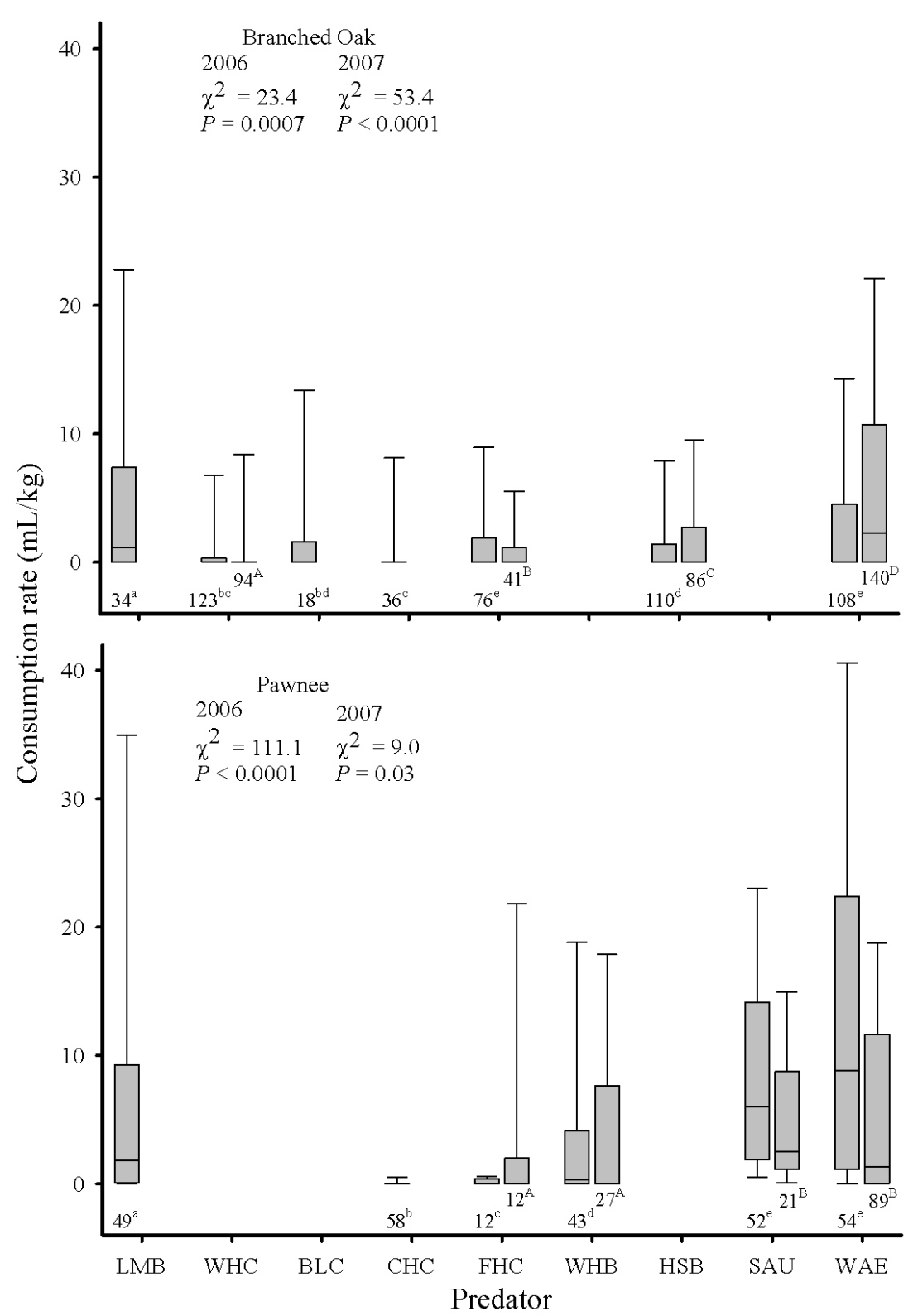

Figure 1

Box plots (showing 10th, 25th, 50th, 75th, and 90th percentiles) of consumption rate on white perch for predators $(L M B=$ largemouth bass, $W H C=$ white crappie, $B L C=$ black crappie, $C H C=$ channel catfish, $F H C=$ flathead catfish, $W H B=$ white bass, $H S B=$ hybrid striped bass, $S A U=$ sauger, $W A E=$ walleye) captured in Branched Oak and Pawnee reservoirs, Nebraska during 2006 and 2007. Sample size for each predator is provided below the box plot; predators within a year (lower-case superscripts for 2006 and upper-case superscripts for 2007) with the same letter are not statistically $(\alpha=0.05)$ different.

(Gosch et al., 2010); similar predator shifts to gizzard shad have been well documented in Midwest reservoirs (e.g., Kocovsky and Carline, 2001; Quist et al., 2002; Hanten, 2006; Ward et al., 2007; Graeb, 2008). Piscivores frequently select soft-rayed fishes (e.g., gizzard shad) over spiny-rayed fishes (e.g., white perch) when given the choice (Beyerle and Williams, 1968; Mauck and Coble, 1971; Wahl and Stein, 1988; Knight and Vondracek, 1993). Furthermore, gizzard shad have a greater caloric density than most other freshwater fishes (Miranda and Muncy, 1989), including white perch, which thereby provides another incentive for the selection of gizzard shad over white perch. Thus, the presence of gizzard shad likely reduces predation pressure on white perch in Branched Oak Lake (Chizinski, 2007; Gosch et al., 2010). 


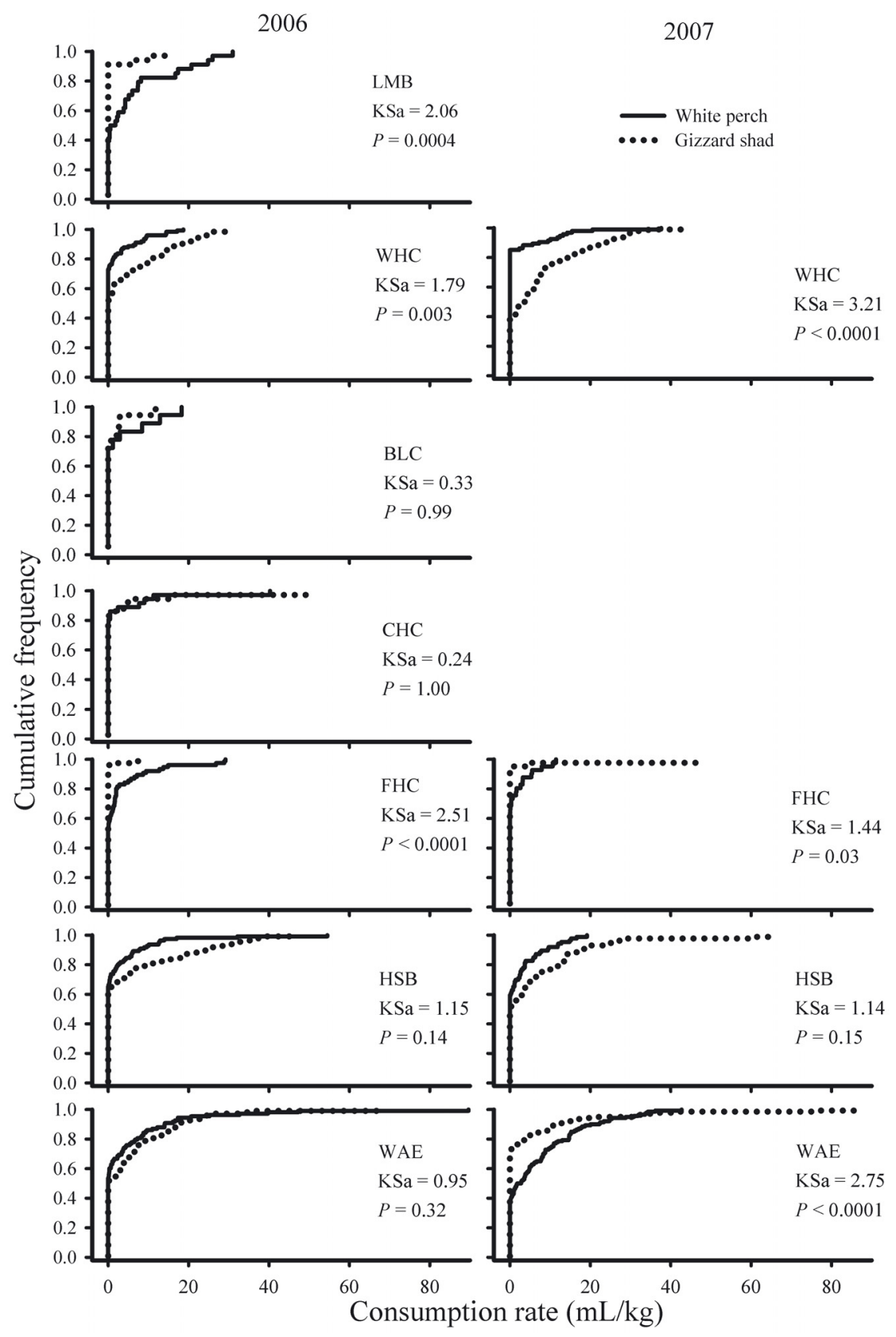

\section{Figure 2}

Cumulative frequency distributions of consumption rate $\left(\mathrm{mL} \cdot \mathrm{kg}^{-1}\right)$ on white perch (solid line) and gizzard shad (dotted line) for predators $(L M B=$ largemouth bass, $W H C=$ white crappie, BLC = black crappie, $\mathrm{CHC}=$ channel catfish, FHC = flathead catfish, HSB = hybrid striped bass, WAE = walleye) captured in Branched Oak Lake, Nebraska during 2006 and 2007.

Predation as a biological control has experienced some previous success. Flathead catfish successfully controlled stunted or undesirable fishes in small hatchery ponds (Hackney, 1966; Swingle, 1967; Crowell, 1976) and in a Texas reservoir (Bamberg, 1975). In Poland, three successive spring stockings of young-of-the-year pike Esox lucius successfully controlled the density of juvenile stages of planktivorous roach Rutilus rutilus, white bream Blicca bjoerkna and sunbleak Leucaspius delineatus (Prejs et al., 1994, 1997). Predation by perch Perca fluviatilis (age $\geqslant 1)$ majorly affected the population dynamics of pikeperch Sander lucioperca and perch in a German reservoir (Dorner and Wagner, 2003). 
Predation as a biological control is not always successful. Largemouth bass and walleye were ineffective in controlling yellow bass Morone mississippiensis, a closely related species to the white perch, in Twelve Mile Lake, lowa (Sobotka, 2005). Similarly, largemouth bass were also ineffective in controlling yellow bass in Viking Lake, lowa (Larson and Boucher, 2005). Furthermore, a review of fish control projects concluded that the stocking of sportfishes to control other fishes was less successful than chemical or mechanical control (Meronek et al., 1996); stocking of sportfishes as a control method was only successful $21 \%$ of the time. Additionally, using predation as a biological control can have unintended effects. For example, piscivorous eels Anguilla anguilla may have reduced the recruitment of a desired piscivore in Bautzen Reservoir while effectively controlling zooplanktivorous fish (Dorner and Benndorf, 2003).

There are many factors that influence consumption rate, and, subsequently, successful biological control via piscivory. For example, most fishes swallow prey items whole (Moyle and Cech, 2004), which can result in gape limitation (Lawrence, 1958; Werner, 1977; Paszkowski and Tonn, 1986; Hambright, 1991). Gape limitation is dependent on predator size and prey body depth; thus, the role of gape limitation will vary according to population size structure of both predators and prey. Gape limitation likely affected consumption rate on white perch more in Pawnee Lake than in Branched Oak Lake because predators were smaller (Gosch et al., 2010) and white perch were larger in Pawnee Lake (Chizinski et al., 2010). When predators are not gape-limited, stomach capacity (i.e., how much the stomach can hold) could be another physical limitation on consumption (Truemper and Lauer, 2005; Gosch et al., 2009). Other factors such as growth rate of predators and prey, predator hunting mode, prey avoidance behavior, and habitat overlap between predators and prey could also influence consumption rate. Further research is needed to determine the applicability of consumption rate in systems containing more diverse prey-fish communities and to determine the influential factors of consumption rate.

\section{ACKNOWLEDGEMENTS}

Special thanks to J. Stittle, L. Pierce, J. Walrath, D. Martin, C. Lewis and T. Barada for field and laboratory assistance. C. Huber, M. Pegg and R. Holland provided valuable comments on an earlier draft of this manuscript. The Nebraska Cooperative Fish and Wildlife Research Unit is jointly supported by a cooperative agreement among the U.S. Geological Survey, the Nebraska Game and Parks Commission, the University of Nebraska, the U.S. Fish and Wildlife Service, and the Wildlife Management Institute. Reference to trade names is for descriptive purposes only and does not imply endorsement by the authors or the U.S. Government.

\section{REFERENCES}

Ballinger R.E. and Peters E.J., 1978. Impact of an introduced fish species (Morone americana) on the fisheries resource of Nebraska. Partial Technical Completion Report and Annual Progress Report, University of Nebraska-Lincoln, USA.

Bamberg R.M., 1975. Experimental Management of Lake Sweetwater. Texas Parks and Wildlife Department, Federal Aid Project F-31-R-1, Final Report, Austin, USA.

Bettoli P.W. and Maceina M.J., 1996. Sampling with toxicants. In: Murphy B.R. and Willis D.W. (eds.), Fisheries Techniques, 2nd edn., American Fisheries Society, Bethesda, 303-333.

Beyerle G.B. and Williams J.E., 1968. Some observations of food selectivity by northern pike in aquaria. Trans. Am. Fish. Soc., 97, 28-31.

Bliss Q. and Schainost S., 1974. Middle Platte Basin stream inventory report. Nebraska Game and Parks Commission, Aquatic Wildlife Division, Bureau of Wildlife Services, Lincoln, USA.

Callam M.A., 1996. Nebraska water quality report. Water Quality Division, Department of Environmental Quality, State of Nebraska, USA. 
Chizinski C.J., 2007. Variation in life-history traits and morphology of stunted and non-stunted fish, Ph.D. thesis, Texas Tech University, $165 \mathrm{p}$.

Chizinski C.J., Pope K.L., Wilde G.R. and Strauss R.E., 2010. Implications of stunting on morphology of freshwater fishes. J. Fish Biol., 76, 564-579.

Crowell T.E., 1976. Effectiveness of flathead catfish as an auxiliary predator. North Carolina Wildlife Resources Commission, Federal Aid Project F-21-5, Final Report, Raleigh, USA.

Dorner H. and Benndorf J., 2003. Piscivory by large eels on young-of-the-year fishes: its potential as a biomanipulation tool. J. Fish Biol., 62, 491-494.

Dorner H. and Wagner A., 2003. Size-dependent predator-prey relationships between perch and their fish prey. J. Fish Biol., 62, 1021-1032.

Gabelhouse Jr. D.W., 1984. A length-categorization system to assess fish stocks. N. Am. J. Fish. Manag., 4, 273-285.

Gosch N.J.C., Pope K.L. and Michaletz P.H., 2009. Stomach capacities of six freshwater fishes. J. Freshw. Ecol., 24, 645-649.

Gosch N.J.C., Pierce L.L. and Pope K.L., 2010. The effect of predation on stunted and non-stunted white perch. Ecol. Freshw. Fish., 19, 401-407.

Graeb B.D.S., Chipps S.R., Willis D.W., Lott J.P., Hanten R.P., Nelson-Stastry W. and Erickson J.W., 2008. Walleye response to rainbow smelt population decline and liberalized angling regulations in a Missouri River reservoir. In: Allen M.S., Sammons S. and Maceina M.J. (eds.), Balancing Fisheries Management and Water Uses for Impounded River Systems, American Fisheries Society Symposium 62, Bethesda, 275-292.

Hackney P.A., 1966. Predator-prey relationships of the flathead catfish in ponds under selected forage fish conditions. Proc. Annu. Conf. Southeast. Assoc. Game Fish Comm., 19, 217-222.

Hambright K.D., 1991. Experimental analysis of prey selection by largemouth bass: role of predator mouth width and prey body depth. Trans. Am. Fish. Soc., 120, 500-508.

Hanten R., 2006. Seasonal food habits, condition, growth and distribution of Lake Oahe, South Dakota walleye during depressed prey fish conditions spring 2001 to spring 2002. South Dakota Department of Game, Fish and Parks, Fisheries Division Report 07-02, Pierre, USA.

Hergenrader G.L., 1980. Current distribution and potential for dispersal of white perch (Morone americana) in Nebraska and adjacent waters. Am. Midl. Nat., 103, 404-406.

Hergenrader G.L. and Bliss Q.P., 1971. The white perch in Nebraska. Trans. Am. Fish. Soc., 100, 734-738.

Hodkin C.E., 2001. Population characteristics and food habits of white perch (Morone americana) in Branched Oak Lake, Nebraska, M.S. thesis, University of Nebraska-Lincoln, 83 p.

Jackson J., 1999. Branched Oak white perch control plan. Nebraska Game and Parks Commission, Lincoln, USA.

Jackson J., 2008. Pawnee reservoir management plan. Nebraska Game and Parks Commission, Lincoln, USA.

Kamler J.F. and Pope K.L., 2001. Nonlethal methods of examining fish stomach contents. Rev. Fish. Sci., 9, 1-11.

Knight R.L. and Vondracek B., 1993. Changes in prey fish populations in western Lake Erie, 1969-1988, as related to walleye, Stizostedion vitreum, predation. Can. J. Fish. Aquat. Sci., 50, 1289-1298.

Kocovsky P.M. and Carline R.F., 2001. Influence of extreme temperatures on consumption and condition of walleyes in Pymatuning Sanctuary, Pennsylvania. N. Am. J. Fish. Manag., 21, 198-207.

Kuklinski K.E., 2007. Ecological investigation of the invasive white perch in Kaw Lake, Oklahoma. Proc. Okla. Acad. Sci., 87, 77-84.

Larson C. and Boucher M., 2005. Stocking walleye as an experimental method of controlling yellow bass in Viking Lake. Fisheries management section completion reports, lowa Department of Natural Resources, Des Moines, USA.

Lawrence J.M., 1958. Estimated sizes of various forage fishes largemouth bass can swallow. Proc. Annu. Conf. Southeast. Assoc. Fish. Wildl. Agencies, 11, 220-225.

Light R.W., Alder P.H. and Arnold D.E., 1983. Evaluation of gastric lavage for stomach analysis. N. Am. J. Fish. Manag., 3, 81-85. 
Mansueti R.J., 1961. Movements, reproduction, and mortality of the white perch, Roccus americanus, in the Patuxent estuary, Maryland. Chesapeake Sci., 2, 142-205.

Mauck W.L. and Coble D.W., 1971. Vulnerability of some fishes to northern pike (Esox lucius) predation. J. Fish. Res. Board Can., 28, 957-969.

Meronek T.G., Bouchard P.M., Buckner E.R., Burri T.M., Demmerly K.K., Hatleli D.C., Klumb R.A., Schmidt S.H. and Coble D.W., 1996. A review of fish control projects. N. Am. J. Fish. Manage., 16, 63-74.

Miranda L.E. and Muncy R.J., 1989. Bioenergetic values of shads and sunfishes as prey for largemouth bass. Proc. Annu. Conf. Southeast. Assoc. Fish. Wildl. Agencies, 43, 153-163.

Moyle P.B. and Cech J.J., 2004. Fishes: An Introduction to Ichthyology, 5th edn., Prentice-Hall, Inc., Upper Saddle River, USA.

Paszkowski C.A. and Tonn W.M., 1994. Effects of prey size, abundance, and population structure on piscivory by yellow perch. Trans. Am. Fish. Soc., 123, 855-865.

Porath M.T., 2006. Climate and habitat factors related to a localized extirpation of gizzard shad (Dorosoma cepedianum). Great Plains Res., 16, 127-135.

Prejs A., Martyniak A., Boron S., Hliwa P. and Koperski, P., 1994. Food web manipulation in a small, eutrophic Lake Wirbel, Poland: effects of stocking with juvenile pike on planktivorous fish. Hydrobiologia, 275/276, 65-70.

Prejs A., Pijanowska J., Koperski P., Martyniak A., Boron S. and Hliwa P., 1997. Food web manipulation in a small, eutrophic Lake Wirbel, Poland: long-term changes in fish biomass and basic measures of water quality. A case study. Hydrobiologia, 342/343, 383-386.

Quist M.C., Guy C.S., Bernot R.J. and Stephen J.L., 2002. Seasonal variation in condition, growth and food habits of walleye in a Great Plains reservoir and simulated effects of an altered thermal regime. J. Fish Biol., 61, 1329-1344.

Scott W.B. and Crossman E.J., 1973. Freshwater fishes of Canada, Fisheries Research Board of Canada, Bulletin 184, Ottawa.

Sierp M.T., Qin J.G. and Recknagel F., 2009. Biomanipulation: A review of biological control measures in eutrophic waters and the potential for Murray cod Maccullochella peelii peelii to promote water quality in temperate Australia. Rev. Fish Biol. Fish., 19, 143-165.

Sobotka G.L., 2005. Evaluation of walleye and largemouth bass in controlling yellow bass at Twelve Mile Lake. Fisheries management section completion reports, lowa Department of Natural Resources, Des Moines, IA, USA.

Swingle H.S., 1967. Experiments with the flathead catfish ("Pylodictis olivaris") in ponds. Proc. Annu. Conf. Southeast. Assoc. Game. Fish. Comm., 18, 303-308.

Thistle M.E., 2006. Distribution and risk-sensitive foraging of juvenile gadids in relation to fractal complexity of eelgrass (Zostera marina) habitat, M.S. thesis, Memorial University of Newfoundland.

Truemper H.A. and Lauer T.E., 2005. Gape limitation and piscine prey size-selection by yellow perch in the extreme southern area of Lake Michigan, with emphasis on two exotic prey items. J. Fish. Biol., 66, 135-149.

Vrtiska L., Hodkin C.E., Severn A., Peters E.J. and Hoagland K.D., 2001. Branched Oak Reservoir project final report, Federal Aid Project F-133-R. Nebraska Game and Parks Commission, Lincoln, USA.

Wahl D.H. and Stein R.A., 1988. Selective predation by three esocids: the role of prey behavior and morphology. Trans. Am. Fish. Soc., 117, 142-151.

Ward M.J., Willis D.W., Miller B.H. and Chipps S.R., 2007. Walleye consumption and long-term population trends following gizzard shad introduction into a western South Dakota reservoir. J. Freshw. Ecol., 22, 339-345.

Werner E.E., 1977. Species packing and the niche complementarity in three sunfishes. Am. Nat., 111, 553-578.

Wydoski R.S. and Wiley R.W., 1999. Management of undesirable fish species. In: Kohler C.C. and Hubert W.A. (eds.), Inland Fisheries Management in North America, 2nd edn., American Fisheries Society, Bethesda, 403-430. 